\title{
KEBUTUHAN BELAJAR MASYARAKAT UNTUK PENGEMBANGAN WISATA BELAJAR DI WADUK GAJAH MUNGKUR KABUPATEN WONOGIRI
}

\author{
Tristanti dan Fitta Ummaya Santi \\ Fakultas Ilmu Pendidikan Universitas Negeri Yogyakarta \\ email: tristanti@uny.ac.id
}

\begin{abstract}
Abstrak: Kebutuhan Belajar Masyarakat untuk Pengembangan Wisata Belajar di Waduk Gajah Mungkur Kabupaten Wonogiri. Penelitian ini bertujuan untuk mendeskripsikan: (1) kebutuhan belajar masyarakat di Waduk Gajah Mungkur sebagai upaya pengembangan wisata belajar dan (2) kendala yang dihadapi dalam pengembangan wisata belajar di Waduk Gajah Mungkur. Penelitian ini merupakan penelitian deskriptif kualitatif dengan subjek penelitian adalah masyarakat sekitar Waduk Gajah Mungkur yang terdiri dari pengelola, wisatawan, dan pedagang. Hasil penelitian menunjukkan bahwa: pertama, keberadaan wisata Waduk Gajah Mungkur sangat bermanfaat bagi kehidupan masyarakat sekitar waduk sebagai pemenuhan kebutuhan hidup dan menambah perekonomian. Wisata Waduk Gajah Mungkur juga dipandang dapat menumbuhkan peluang sebagai wisata belajar yaitu kegiatan outbound, wisata edukasi, dan wisata memancing. Kedua, kendala yang dihadapi dalam pengembangan Wisata Waduk Gajah Mungkur yaitu kemampuan sumber daya manusia masih minim, belum adanya koordinasi antarpengelola waduk dengan dinas pariwisata dan kesadaran masyarakat terhadap pengembangan waduk masih rendah.
\end{abstract}

Kata kunci: kebutuhan belajar, wisata belajar, Waduk Gajah Mungkur

\begin{abstract}
Community Learning Needs for Tourism Learning Development Program at Waduk Gajah Mungkur, Wonogiri. This study was aimed at describing: (1) community learning needs in Waduk Gajah Mungkur as an effort to develop learning tourism and (2) obstacles faced in developing learning tourism in Waduk Gajah Mungkur. This research was a qualitative descriptive research using Waduk Gajah Mungkur citizen as the research subject. They were managers, tourists, and traders. The results showed that: first, the existence of Waduk Gajah Mungkur tourism gives many benefits for the life of the community around the reservoir as the fulfillment of the necessities of life and to increase the society welfare. Waduk Gajah Mungkur also develop learning tourism through outbound activities, educational tours, and fishing tours. Secondly, the obstacles faced in the development of the Waduk Gajah Mungkur are the lack of human resources, the lack of coordination between the reservoir managers and the tourism office and the lack of awareness of the reservoir development.
\end{abstract}

Keywords: learning needs, learning tours, Waduk Gajah Mungkur 


\section{PENDAHULUAN}

Perkembangan kebutuhan belajar masyarakat dewasa ini semakin meningkat seiring dengan perubahan kehidupan. Kebutuhan belajar seseorang dapat dipenuhi melalui lingkungan sekitar di mana kegiatan belajar tidak hanya terbatas dalam ruangan akan tetapi bisa terjadi di luar ruangan dengan memanfaatkan berbagai sumber daya alam yang ada. Saat ini, belajar berbasis alam sedang menjadi tren tersendiri karena seseorang dapat menikmati suasana alam sekaligus mendapatkan pengetahuan baru. Dalam bahasa wisatanya sering kita dengar dengan slogan "back to nature". Konsep kembali ke alam didasari oleh tantangan pembangunan pada abad 21 yaitu: (a) tuntutan untuk menampung akibat bertambahnya pendudukyang dihadapkan dengan sumber-sumber yang terbatas, (b) tantangan dalam mengahpuskan kemiskinan, dan (c) tantangan akan permintaan sumber-sumber alam yang semakin besar (Syahid, 2016).

Belajar berbasis alam dapat dilakukan di tempat-tempat wisata khususnya wisata alam seperti Waduk Gajah Mungkur yang terletak di Kabupaten Wonogiri. Waduk Gajah Mungkur Wonogiri atau sering dikenal juga dengan sebutan Bendungan Serbaguna Wonogiri ini merupakan sebuah ikon yang sangat terkenal di Kabupaten Wonogiri. Bendungan ini merupakan waduk terbesar se-Indonesia yang dibangun dengan fungsi utama sebagai pengendali banjir (flood control) Sungai Bengawan Solo. Letaknya $3 \mathrm{~km}$ di selatan Kabupaten Wonogiri. Perairan bendungan ini berasal dari sungai terpanjang di Pulau Jawa, yakni sungai Bengawan Solo. Luasnya sekitar 8800 ha, bisa mengairi sawah seluas 23600 ha di daerah Sukoharjo, Klaten, Karanganyar dan Sragen. Selain berfungsi sebagai pengendali banjir juga berfungsi sebagai objek wisata. Dalam hal ini pemerintah Wonogiri memiliki kebijakan untuk mengembangkan Waduk Gajah Mungkur menjadi waduk yang bisa berfungsi baik sebagai tempat wisata tetapi juga sebagai tempat belajar masyarakat.

Wisata belajar merupakan kegiat-an belajar yang dilakukan dengan mengunjungi atau mengakses tempat-tempat wisata sebagai sumber informasi dan pengetahuan. Menurut Moeslichatoen (2004) wisata belajar dijelaskan sebagai kegiatan pengajaran dengan dunia luar secara langsung yang mendorong anak untuk memperoleh kesan yang sesuai dengan apa yang diamati. Wisata belajar sangat berhubungan dengan konsep ecotourism yaitu pariwisata berwawasan lingkungan. Dalam penyelenggaraannya dilakukan dengan kesederhanaan, memelihara keaslian alam dan lingkungan, memelihara keaslian seni dan budaya, adat-istiadat, kebiasaan hidup (the way of life), menciptakan ketenangan, kesunyian, memelihara flora dan fauna, serta terpeliharanya lingkungan hidup sehingga tercipta keseimbangan antara kehidupan manusia dengan alam sekitarnya. Ekowisata memiliki empat unsur yang dianggap penting, yaitu unsur pro-aktif, kepedulian terhadap pelestarian lingkungan hidup, keterlibatan penduduk lokal, unsur pendidikan. Wisatawan yang datang tidak semata-mata untuk menikmati alam sekitarnya tetapi juga mempelajarinya sebagai peningkatan pengetahuan atau pengalaman.

Wisata belajar atau sering disebut dengan study tour yang menurut sifatnya merupakan aktivitas pendidikan, kegiatan ini menawarkan peserta untuk melihat jendela pada dunia. Kegiatan ini juga mampu memberikan inspirasi dan katalisator untuk mendiskusikan tentang masa depan yang membutuhkan studi lebih lanjut, lokasi wisata belajar 
juga merupakan sumber pasti subyektif dari wawasan daripada bukti formal (Rushforth, et al., 2008). Dalam situasi seperti ini, pembelajaran harus mampu memberikan kontribusi nyata terhadap perubahan sikap dan perilaku warga belajar dalam kehidupan sehari-hari (King, 2005). Sujarwo, Samsi, dan Wibawa (2017) menyatakan program wisata belajar merupakan program pengembangan pendidikan di luar sekolah (pendidikan non formal) melalui pembelajaran outing clas yang dapat mem-berikan kemudahan akses kepada peserta didik agar dapat belajar secara nyata. Pendapat lain dikemukakan Kindervatter (1979) bahwa pembelajaran masyarakat harus memiliki muatan pemberdayaan agar masyarakat sebagai subjek belajar memiliki kemandirian dalam kehidupannya agar dapat beraktualisasi diri.

Hardika (2013) menyatakan bahwa pemberian kebebasan kepada masyarakat untuk beraktualisasi dalam belajar usaha (wirausaha) merupakan hal penting dalam upaya pemberdayaan masyarakat. Strategi pembelajaran masyarakat harus lebih banyak difokuskan pada aspek pemberdayaan untuk menuju kemandirian dalam mengatasi persoalan diri, dan lingkungannya. Masyarakat sebagai pelaku belajar harus diberi akses dalam memperoleh sumber belajar, daya tawar yang lebih kuat, pilihan untuk menentukan sikap, status harga diri, peningkatan sikap kritis, dan pengakuan terhadap eksistensinya, agar mereka lebih berperan dan memiliki kepercayaan diri.

Kelebihan yang akan diperoleh dari kegiatan wisata belajar adalah dapat memperoleh pengalaman secara langsung sehingga kegiatan pembelajaran dapat bermakna, memperbanyak pengalaman, dan pengetahuan peserta baik di dalam maupun di luar kelas, memberikan kesenangan peserta terhadap alam sekitarnya (Husamah, 2013). Banyaknya manfaat yang bisa dikembangkan dengan adanya Waduk Gajah Mungkur tentunya akan memberikan dampak yang positif juga bagi masyarakat sekitar. Akan tetapi manfaat tersebut harus didukung pula oleh masyarakat itu sendiri. Selama ini daya dukung dari masyarakat sekitar masih rendah karena masyarakat belum memiliki pengetahuan serta keterampilan dalam pengembangan waduk Gajah Mungkur tersebut. Masyarakat belum mengetahui akan potensi yang dimiliki pada dirinya serta belum mengetahui potensi yang ada pada wisata Waduk Gajah Mungkur. Dengan demikian, perlu dilakukan identifikasi kebutuhan belajar masyarakat di Waduk Gajah Mungkur dalam pengembangan wisata belajar.

\section{METODE}

Penelitian ini dilaksanakan di Wisata Waduk Gajah Mungkur di Kabupaten Wonogiri. Penelitian ini merupakan penelitian deskriptif kualitatif yaitu mengungkap kebutuhan masyarakat di sekitar Waduk Gajah Mungkur dalam pengembangan wisata belajar serta faktor pendukung dan penghambat dalam pengembangan wisata Waduk Gajah Mungkur di Kabupaten Wonogiri. Subjek dalam penelitian ini adalah masyarakat sekitar Waduk Gajah Mungkur, yang terdiri dari pengelola, tokoh masyarakat, dan pengunjung wisata. Data dikumpulkan melalui wawancara secara mendalam, observasi, dan dokumentasi. Teknik analisis data yaitu menggunakan teknik analisis kualitatif dengan model interaktif (Miles \& Huberman, 2007). Untuk memperoleh data yang valid, teknik triangulasi, perpanjangan pengamatan dan diskusi terfokus dilakukan. 


\section{HASIL DAN PEMBAHASAN}

Keberadaan Waduk Gajah Mungkur sangat mendukung kehidupan masyarakat sekitarnya khususnya dalam hal pengairan. Selain itu, masyarakat dapat meningkatkan perekonomian keluarga melalui aktivitas berdagang di objek wisata Waduk Gajah Mungkur. Namun demikian, daya tarik wisatawan ke Waduk Gajah Mungkur mengalami pasang surut tergantung pada musim libur sekolah atau tidak.

Kunjungan di objek wisata Gajah Mungkur mengalami peningkatan yang tinggi di saat libur nasional misalnya saat libur sekolah atau saat libur hari raya. Selama kurun waktu bulan Februari sampai dengan Juli tahun 2017 terus mengalami peningkatan dari jumlah 21.142 pengunjung sampai 62.690 pengunjung, sedangkan di bulan berikutnya mengalami penurunan sekitar 4.000 pengunjung. Berdasarkan keterangan Bapak Pardianto (Kepala UPT Waduk Gajah Mungkur), Jumlah pengunjung pada hari biasa mencapai angka 500-1.000 pengunjung dan pada tahun baru dapat mencapai 35.000 pengunjung. Untuk menarik pengunjung, misalnya pada hari libur, pengelola menyediakan paket-paket wisata. Paket wisata yang dimaksud adalah tiket masuk yang relatif lebih murah dibanding dengan hari-hari biasa. Tiket masuk untuk hari biasa sebesar lima ribu rupiah, sedangkan untuk hari libur sebesar tiga ribu rupiah.

Kegiatan wisata belajar di Waduk Gajah Mungkur sampai saat ini belum pernah diadakan oleh pengelola UPT Waduk Gajah Mungkur. Sampai saat ini juga perhatian dinas pariwisata belum pernah mengadakan kegiatan pelatihan terkait pengembangan waduk sebagai objek wisata sekaligus tempat belajar. Aktivitas yang dilakukan pengelola dalam pengelolaan waduk yaitu mengadakan kegiatan briefing yang dilaksanakan setiap pagi oleh internal UPT Waduk Gajah Mungkur sendiri. Briefing tersebut berisi pelaksanaan program kerja yang dilaksanakan oleh UPT Waduk Gajah Mungkur. Adapun manfaat dari kegiatan briefing tersebut adalah untuk meningkatkan kedisiplinan dan kinerja staff pengelola UPT Waduk Gajah Mungkur. Selain itu, briefing tersebut juga dilaksanakan untuk menyampaikan program kerja yang akan dilaksanakan serta mengevaluasi program kerja yang sudah berjalan. Program kerja yang ada di Objek Wisata Waduk Gajah Mungkur meliputi beberapa program yaitu program rutin dan event tahunan. Program rutin tersebut merupakan program wajib yang selalu dilaksanakan yaitu tentang kebersihan, peningkatan kunjungan serta fasilitas. Program tahunan yang dilaksanakan yaitu event wisata contohnya Grebeg Suro, Tahun Baru Masehi, dan Idul Fitri. Objek Wisata Waduk Gajah Mungkur memiliki arena outbound yang dikelola oleh UPT Waduk Gajah Mungkur namun untuk pemandu outbound-nya didatangkan dari luar.

Selain belum adanya kegiatan pelatihan bagi para pengelola Waduk Gajah Mungkur, masyarakat sekitar waduk juga belum pernah menerima kegiatan pelatihan dari lembaga nonformal atau dari dinas pariwisata setempat. Para pedagang yang sudah lama tinggal di sana bertahun-tahun hanya mengandalkan dari keterampilan yang dimiliki sendiri. Mereka berasal dari luar daerah dan sudah lama menetap di Wonogiri. Barang-barang yang mereka dagangkan berupa pernak-pernik atau aksesoris, makanan, dan minuman, serta ikan hasil nelayan di waduk. Para pedagang selain memproduksi dagangan sendiri juga mengambil dagangan dari produksi orang lain.

Pengunjung objek Wisata Gajah Mungkur memiliki tujuan yang berbeda- 
beda. Sebagian besar berkunjung untuk menikmati keindahan alam yang sejuk, sebagian berkunjung untuk kegiatan outbound dan sebagian lagi berkunjung untuk kegiatan memancing. Kegiatan outbound biasanya dilakukan oleh instansi-instansi secara rombongan dengan tujuan penguatan sumber daya manusia instansi tersebut. Kesejukan udara dan keindahan alam yang masih asri membuat wisatawan berkunjung ke waduk tidak hanya satu kali tetapi beberapa kali. Dengan demikian, Waduk Gajah Mungkur memiliki daya tarik tersendiri yang dibawa dari alam. Keindahan ini akan semakin menarik wisatawan jika pengelola waduk memberikan kegiatan-kegiatan bernuansa edukasi baik bagi orang dewasa ataupun anak-anak.

Kepemanduan dan wisata edukasi tidak hanya dibutuhkan oleh sedikit pengunjung wisata Waduk Gajah Mungkur. Sebagian besar wisatawan menginginkan adanya kegiatan tersebut, akan tetapi pihak pengelola waduk belum bisa melayani secara maksimal. Fasilitas yang tersedia di Waduk Gajah Mungkur meliputi fasilitas toilet, tempat ibadah, tempat parkir kendaraan, tempat bermain, spot foto, dan tempat kuliner. Fasilitas waduk yang belum termanfaatkan secara maksimal adalah tempat bermain untuk anak-anak dan juga arena outbound. Hal tersebut dikarenakan kurangnya pengelolaan dari pengelola Waduk Gajah Mungkur. Keterbatasan pengetahuan dari sumber daya manusia juga menjadi alasan tersendiri. Wisatawan menginginkan adanya wisata edukasi dengan alasan menambah pengetahuan bagi pengunjung dan juga menambah daya tarik tersendiri dari Waduk Gajah Mungkur. Lokasi Waduk Gajah Mungkur yang strategis juga menjadi alasan wisatawan berkunjung.

Fasilitas lain yang menjadi perhatian yaitu terkait area pemancingan. Area pemancingan menjadi area yang bebas bagi para wisatawan sehingga ada wisatawan yang sengaja datang ke waduk hanya untuk memancing. Menurut informasi yang berasal dari para pemancing, wisata waduk memiliki ikan yang banyak dan memiliki nuansa yang menyenangkan untuk kegiatan memancing. Akan tetapi, pengelolaan tempat memancing yang kurang mendukung mengakibatkan wisatawan kurang tertarik lagi untuk melakukan aktivitas memancing. Selain ketertarikan akan area pemancingan di waduk, para wisatawan juga tertarik dengan kuliner yang ada di sekitar waduk. Kuliner tersebut meliputi jambu mete yang diolah menjadi manisan dan juga kacang mete, ketela pohon, kacang tanah, pecel brambang asem, dan ikan hasil tangkapan di waduk.

Pengembangan wisata Waduk Gajah Mungkur sebagai wisata belajar dapat dilakukan dengan mengoptimalkan potensi-potensi yang dimiliki waduk tersebut. Untuk mengoptimalkan potensi sumber daya alam tersebut tentunya diperlukan kualitas sumber daya manusia yang berkualitas juga. Pengembangan wisata belajar juga harus memperhatikan akan kebutuhan dari masyarakat pengguna. Wisata Waduk Gajah Mungkur merupakan wisata alam dengan potensi alam yang bisa dikembangkan sebagai wisata belajar. Kebutuhan akan wisata belajar itu sendiri berasal dari keinginan dari wisatwan yang berkunjung. Hal ini dimaksudkan agar kegiatan wisata tidak membosankan, karena hanya menikmati alam tanpa ada aktivitas yang bermakna. Dengan adanya aktivitas yang bermakna maka pengunjung akan menikmatinya kembali pada kesempatan yang lain. Wisata belajar diartikan sebagai kegiatan wisata pendidikan yang dilakukan oleh sekelompok orang untuk mendapatkan kesan yang bermakna sesuai yang diamati. 
Tujuan dari wisata belajar itu sendiri adalah untuk melestarikan budaya atau objek yang diamati dan juga mendapatkan pengetahuan dari objek yang diamati. Waduk Gajah Mungkur memiliki manfaat danjuganilaibudayayang perlu dilestarikan sebagai kekayaan hayati. Wisata belajar merupakan metode pembelajaran yang dikemas secara rekreatif namun tetap menonjolkan unsur-unsur edukasi. Wisata belajar memungkinkan wisatawan untuk dapat refreshing dan melepas kepenatan pikiran sekaligus membelajarkan apabila direncanakan dengan baik. Husamah (2013:54) menjelaskan bahwa terdapatsisi positif bagi seorang siswa yang mengikuti kegiatan wisata belajar khususnya di kebun binatang, yaitu: kegiatan belajar mengajar lebih bermakna sebab siswa memperolehnya dengan mengalaminya secara langsung; membangkitkan sisi eksploratif siswa dalam usahanya menyelesaikan sesuatu; memperlihatkan kondisi nyata di lapangan dengan mengintegrasikannya dengan pengajaran di dalam kelas sehingga menciptakan kepribadian yang komplit baik bagi guru maupun siswa; memperbanyak pengetahuan dan wawasan yang diperoleh siswa baik di dalam maupun luar kelas; dan memberikan kesenangan siswa terhadap alam sekitarnya.

Konsep penggabungan antara wisata dan belajar ini memiliki banyak bentuk dan variasi, antara lain: karyawisata, studytour, outbound, outingclass, dan wisata edukasi. Lokasi yang digunakan dalam melaksanakan pembelajaran model ini pun sangat beragam karena menyesuaikan kebutuhan dan informasi yang ingin digali. Manfaat waduk yang selama ini dirasakan hanya terbatas pada fungsi irigasi, dapat dikembangkan ke arah wisata edukasi sehingga dapat mengembangkan perekonomian masyarakat sekitar. Oleh karenanya perlu adanya pengembangan waduk untuk menjadi wisata edukasi.

Fungsi Waduk Gajah Mungkur selain sebagai irigasi untuk pertanian dan kebutuhan air masyarakat sekitar juga dapat difungsikan sebagai tempat edukasi. Misalnya air yang berada di waduk dapat dijadikan sebagai sumber belajar bagi anak-anak yang berkunjung di waduk. Selain itu, adanya area taman satwa dapat juga dijadikan sebagai sumber belajar bagi pengunjung waduk. Binatang-binatang yang ada di sana dapat dijadikan sebagai pembelajaran anak-anak untuk lebih memahami tentang binatang. Kegiatan di waduk tidak hanya sebatas pada kegiatan melihat waduk dan menikmati udara segar, akan tetapi dapat juga melakukan aktivitas fisik seperti field trip dan outbound. Wisatawan membutuhkan kepemanduan dalam mengunjungi waduk agar mereka dapat maksimal dalam mendapatkan informasi, pengetahuan dan pengalaman. Kegiatan kepemanduan dapat dikemas dalam bentuk field trip. Sagala (2006: 214) menyebutkan fieldtrip sebagai pesiar (ekskursi) yang dilakukan oleh peserta didik untuk melengkapi pengalaman belajar tertentu dan merupakan bagian integral dari kurikulum sekolah. Metode ini banyak digunakan selain untuk memperkaya wawasan dan pengetahuan peserta didik, juga untuk menghindari kebosanan serta kejenuhan peserta didik terhadap pembelajaran yang ada di kelas. Kegiatan field trip tidak hanya diperuntukkan bagi anak-anak akan tetapi dapat juga dikemas untuk orang dewasa. Area Waduk Gajah Mungkur yang sangat luas dan indah dapat dijelajahi dengan menggunakan kereta kelinci sehingga lebih memberikan kesan tersendiri bagi wisatawan.

Wisata Waduk Gajah Mungkur juga memungkinkan untuk kegiatan outbound sebagai wisata edukasi. Kegiatan outbound 
tidak hanya diperuntukkan bagi anakanak tetapi juga bisa bagi orang dewasa. Kegiatan outbound di Waduk Gajah Mungkur sangat dimungkinkan untuk dilakukan karena banyak area yang bisa dijadikan sebagai tempat outbound. Area air yang sangat luas dapat dijadikan sebagai tempat outbound air atau permainan-permainan di air. Begitu juga dengan lokasi daratan yang luas juga dapat didesain untuk area outbound. Makna dari kegiatan outbound tidak hanya dimaknai sebagai kegiatan di luar. Namun, lebih dari itu dimana peserta diajak berpikir kreatif dan membuat terobosan-terobosan baru. Bentuk kegiatan outbound berdasarkan pada prinsip kreativitas, rekreatif, dan edukatif baik dengan sasaran individu maupun kelompok.

Area lain yang menjadi pusat perhatian dari para pengunjung adalah area pemancingan. Banyak wisatawan yang berkunjung berkali-kali hanya untuk menikmati aktivitas memancing di waduk. Banyaknya ikan sebagai potensi waduk menjadi daya tarik tersendiri. Aktivitas seperti ini akan semakin mengundang masyarakat luas jika bisa dikemas dalam aktivitas penyaluran hobi yaitu fishing atau mancing mania.

Dalam mewujudkan konsep wisata belajar memerlukan keterlibatan berbagai pihak yang terkait antara pengelola Waduk Gajah Mungkur dan masyarakat. Sumber daya manusia (SDM) pengelola Waduk Gajah Mungkur dapat dikatakan masih minim akan pengetahuan tentang wisata belajar tersebut. Hal ini dikarenakan SDM yang ada di waduk belum pernah mendapatkan pelatihan ataupun kegiatan bernuansa edukatif untuk mengembangkan wisata Waduk Gajah Mungkur. Kegiatan yang selama ini dilakukan oleh pihak pengelola hanya sebatas kegiatan koordinasi internal terkait pelaksanaan aktivitas rutin harian. Perlunya pelatihan
SDM bagi pengelola Waduk Gajah Mungkur adalah untuk meningkatkan pengetahuan dalam pengemabangan wisata. Kegiatan outbound yang selama ini ada di waduk didatangkan dari luar. Ketika ada permintaan untuk kegiatan outbound dari wisatawan maka pihak pengelola mencarikan pemandu outbound dari luar. Jika pengelola waduk memiliki keterampilan terkait outbound maka dapat memberikan pelayanan terhadap wisatawan secara maksimal. Selain itu, tentu saja akan menambah pendapatan wisata waduk juga. Oleh karena itu, pelatihan bagi SDM sangat penting untuk dilakukan mengingat kebutuhan akan pengunjung yang semakin tertarik menikmati wisata Waduk Gajah Mungkur.

Masyarakat sekitar yang terlibat langsung dalam kegiatan wisata Waduk Gajah Mungkur juga belum pernah mendapatkan pelatihan dari dinas terkait atau dari pemerhati wisata. Masyarakat tersebut adalah para pedagang yang sudah lama menetap di daerah waduk untuk menjajakan dagangannya berupa makanan dan aksesoris. Mereka tidak memproduksi sendiri terkait barang dagangannya, akan tetapi membeli dari produsen. Dalam hal ini, kegiatan pelatihan yang berorientasi pada life skill menjadi penting untuk diperhatikan. Daerah Wonogiri memiliki kekayaan alam yang melimpah seperti singkong, mete dan kacang tanah. Akan tetapi, sumber daya alam tersebut belum diolah secara optimal, pengolahan masih bersifat sederhana sehingga belum memberikan kekhasan makanan khas Wonogiri. Oleh karena itu, perlunya kesadaran masyarakat dan juga pihak pemerhati wisata untuk memberikan pelatihan bagi masyarakat untuk mengembangkan makanan lokal khas Wonogiri. Dengan demikian, aktivitas wisata akan terus berkembang karena wisatawan yang datang ke Wonogiri bisa 
jadi tidak hanya tertarik akan keindahan waduk, akan tetapi juga berkesan dengan makanan khas.

Dari berbagai kebutuhan-kebutuhan masyarakat yang ditemukan menjadi bahan pertimbangan untuk kegiatan pengembangan Waduk Gajah Mungkur sebagai wisata belajar. Beberapa program yang dapat dirumuskan disajikan pada Tabel 1.

Dari Tabel 1 dapat disimpulkan bahwa kebutuhan belajar yang dapat dilakukan di wisata Waduk Gajah Mungkur adalah kegiatan-kegiatan yang berorientasi wisata yang bernuansa edukasi. Sujarwo (2007) menyatakan bahwa kebutuhan belajar adalah segala sesuatu yang diinginkan oleh individu atau kelompok yang berhubungan dan pengetahuan, keterampilan dasar, sikap, dan kemampuan tertentu yang dapat dipenuhi melalui proses pembelajaran. Dari hasil identifikasi kebutuhan belajar selanjutnya dibuat program wisata belajar dalam bentuk outbond. Kegiatan outbound, wisata edukasi, dan juga wisata memancing dapat dikembangkan menjadi wisata belajar di wisata waduk. Hal ini dikarenakan adanya potensi-potensi yang bisa digali dan juga adanya kebutuhan yang dirasakan oleh masyarakat khususnya para pengunjung wisata.

Kegiatan pelatihan kuliner dan pelatihan pembuatan kerajinan merupakan kebutuhan masyarakat yang berorientasi pada pendidikan kecakapan hidup. Namun demikian, dalam mewujudkan wisata belajar program-program ini juga mendukung untuk keberlangsungan pengembangan wisata belajar. Objek wisata yang memiliki kuliner khas akan menambah daya tarik wisatawan untuk berkunjung. Oleh karena itu, programprogram tersebut harus saling mendukung satu sama lain. Pemenuhan kebutuhan masyarakat dalam pengembangan wisata waduk tidak hanya berhenti pada pelaksanaan program kegiatan. Akan tetapi, berlanjut pada kegiatan selanjutnya yang saling mendukung. Setelah itu, perlu adanya pendampingan yang maksimal agar apa yangsudah dilaksanakan menghasilkan manfaat bermakna bagi masyarakat.

Dalam penyelenggaraan sebuah program atau pengelolaan objek wisata tentu memiliki faktor pendukung dan juga faktor penghambat. Pengelolaan wisata

Tabel 1. Program-program yang Dapat Dilaksanakan dalam Menunjang Wisata Belajar

\begin{tabular}{|c|c|c|c|}
\hline No & Nama Program & Sasaran & Potensi yang ada \\
\hline 1 & Outbound & $\begin{array}{l}\text { Pengelola wisata Waduk } \\
\text { Gajah Mungkur }\end{array}$ & $\begin{array}{l}\text { Area outbound (air dan } \\
\text { darat), sumber daya } \\
\text { manusia }\end{array}$ \\
\hline 2 & Pelatihan kuliner & Pedagang & $\begin{array}{l}\text { Warung tempat berjualan, } \\
\text { bahan makanan lokal }\end{array}$ \\
\hline 4 & $\begin{array}{l}\text { Pelatihan pembuatan } \\
\text { karajinan }\end{array}$ & $\begin{array}{l}\text { Pedagang, masyarakat } \\
\text { sekitar }\end{array}$ & $\begin{array}{l}\text { Ruko, bahan membuat } \\
\text { kerajinan }\end{array}$ \\
\hline 3 & Wisata edukasi & $\begin{array}{l}\text { Pengelola wisata Waduk } \\
\text { Gajah Mungkur }\end{array}$ & $\begin{array}{l}\text { Sumber daya manusia, } \\
\text { taman satwa }\end{array}$ \\
\hline 4 & Wisata memancing & $\begin{array}{l}\text { Pengelola wisata Waduk } \\
\text { Gajah Mungkur }\end{array}$ & Area memancing \\
\hline
\end{tabular}


wadukyang sudah berjalan selama ini tidak terlepas dari berbagai dukungan meliputi: penyediaan berbagai infrastruktur, area wisata yang beragam, dan program kerja dari pengelola waduk. Selain banyak dukungan dari berbagai hal, dalam pengembangan wisata waduk terdapat beberapa kendala yaitu: pengetahuan SDM yang masih minim, belum adanya pelatihan dan koordinasi dari dinas pariwisata, dan partisipasi masyarakat sekitar masih rendah.

Faktor pendukung yang sudah ada apabila tidak dikelola dengan baik maka akan menjadi faktor penghambat. Oleh karena itu, perlunya pemanfaatan secara maksimal berbagai faktor pendukung yang sudah ada. Hal-hal yang menghambat dalam pengembangan wisata perlu diberikan aksi terhadap SDM agar terjadi perubahan.

\section{SIMPULAN}

Keberadaan wisata Waduk Gajah Mungkur memberikan manfaat bagi masyarakat sekitar dalam hal irigasi dan peningkatan perekonomian melalui kegiatan berdagang. Wisata Waduk Gajah Mungkur juga memberikan peluang untuk dijadikan sebagai wisata belajar karena berbagai potensi yang dimiliki. Keberadaan wisata Waduk Gajah Mungkur sangat bermanfaat bagi kehidupan masyarakat sekitar waduk sebagai pemenuhan kebutuhan hidup dan menambah perekonomian. Wisata Waduk Gajah Mungkur juga dipandang dapat menumbuhkan peluang sebagai wisata belajar yaitu kegiatan outbound, wisata edukasi, dan wisata memancing. Ada beberapa kendala yang dihadapi dalam pengembangan waduk yaitu kualitas sumber daya manusia yang masih rendah dan belum adanya koordinasi dari dinas terkait dalam upaya penyelenggaraan pelatihan serta partisipasi masyarakat terhadap pengembangan waduk masih rendah.

\section{DAFTAR PUSTAKA}

Syahid, A. R. 2016. "Ecotourism Pariwisata Berwawasan Lingkungan". Diunduh dari https://studipariwisata.com/ analisis/ecotourism-pariwisataberwawasan-lingkungan/.

Hardika. 2013. "Pergeseran Pola Kehidupan dan Kebutuhan Belajar Masyarakat Berbasis Model Prismatik". Proceding Seminar Nasional Pengem-bangan Masyarakat Berbasis Modal Sosial. Jurusan PLS FIP UNY, Mei 2013.

Husamah. 2013. Pembelajaran Luar Kelas (Outdoor Learning). Jakarta: Pustaka Karya

Kindervatter, S. 1979. Nonformal Education as an Empowering Process. Amherst: CIE University of Massachusetts.

King, K. P. 2005. Bringing Transformatif Learning to Life. Malabar, Florida: Krieger.

Moeslichatoen. 2004. Metode Pengajaran di Taman Kanak-Kanak. Jakarta: Rineka Cipta.

Rushforth, H. 2008. "Reflections on a Study Tour to Explore History Taking and Physical AssessmentEducation". Nurse Education in Practice, 8(1), 31-40. doiorg/10.1016/j.nepr.2007.02.004.

Sujarwo. 2007. Analisis Kebutuhan Masyarakat.pdf - Diunduh dari http:// staffnew.uny.ac.id/upload/132304795/ pendidikanhandout+-+Analisis +Kebutuhan+Masyarakat.pdf. Diakses 28 September 2017.

Sujarwo, S., Samsi, I., \& Wibawa, L. 2017. Desain model wisata belajar di Kebun Binatang Gembiraloka Yogyakarta sebagai laboratorium luar kampus. Jurnal Pendidikan dan Pemberdayaan Masyarakat, 4(1), 90100. doi:http://dx.doi.org/10.21831/ jppm.v4i1.12535. 